\author{
ANDREW M. SHANKEN \\ OBERLIN COLLEGE
}

\title{
Research on Memorials and Monuments
}

\begin{abstract}
$A^{2}$ RCHiteCtURAL Historians own No special purchase on the study of "memory", but like many scholars in the humanities, in recent years they have paid increasing attention to memorials. American historians made "memory" a central concern beginning in the late I980's, following D avid Lowenthal's T he Past Is a Foreign Country and Pierre Nora's Lieux de $M$ émoire, two of the key texts of the period. ${ }^{I}$ Since then scholars have prospected in the field of memory studies with uncommon zeal. Prompted by the rise of $\mathrm{H}$ olocaust studies as an aging generation of survivors told their tales, by the controversies surrounding the memorialization of the Vietnam War, and by the post-modern dissatisfaction with the purported stability of terms like history, the study of cultural memory seemed to promise a fresh view of the past. The pursuit of the elusive idea of memory in academia rose to a crescendo with the approach of " ${ }_{2} \mathrm{~K}$." The year 2000 had been the finish
\end{abstract}

I. D avid Lowenthal, The Past Is a Foreign Country (Cambridge University Pres, 1985) and Pierre Nora, Lieux de M émoire (Paris, Gallimard, 1984) and translated as Rethinking France (University of C hicago Press, 20oI). Several special issues mark the vigorous attention to history and memory. H istory and Anthropology 2, 2 (1986) was devoted to "M emory and History." The Journal of American H istory ( $M$ arch, 1989) gave an entire issue over to "M emory and American H istory", while Representations 26 (Spring, 1989) followed shortly thereafter with an issue on "M emory and Counter-M emory." Fueled in part by the rising interest, the journal $H$ istory and $M$ emory began in 1989. More recently, the American H istorical Review IO2 (D ec., 1997) revisited the theme in an issue devoted to "H istory and M emory" and an issue of the $\mathrm{H}$ arvard D esign M agazine(Fall, 1989) was dedicated to memorials. 
164

line of the future for more than fifty years, and its approach brought with it a heightened since of commemoration, from the fiftieth anniversary of World War II and the H olocaust, to the fall of the Soviet U nion (and the simultaneous toppling of its memorials). The ferment around issues of memory is of particular interest to architectural historians, who have al ways focused on its material manifestations: memorials and monuments.

In art and architectural history, a steady stream of scholarship over the past decade or so has made the topic of memorials a significant concern for the field. The best broad study of memorials and monuments in the $19^{\text {th }}$ and $20^{\text {th }}$ centuries is Sergiusz M ichalski's Public M onuments, which plays changing conventions in art history, especially in sculpture, against the politics of the era. ${ }^{2}$ The book is particularly fine on what M ichalski calls the statue mania of the Third Empire, the D enkmalkritik that followed with the emergence of modernism, and the parallel but very different course of $G$ erman memorials in the same period. The French experienced a memorial mania in the late I $^{\text {th }}$ century, fueled by the need to prop up fragile national identity in the aftermath of defeat in the Franco-Prussian War in 1871. M emorials in the BeauxArts tradition carried on the work of $H$ aussmann's embellisement, as a part of urban beautification, reinforcing major public spaces and axes first in Paris and soon after in other major cities. In Germany, a more romantic spirit presided, often directly in contrast to the more classical French mode of memorialization. Gigantic, rough-hewn granite monuments to Bismarck, W ilhelm I, and others were erected on hills in the forests of Germany and on the outskirts of cities.

In M ichalski's hands, changes in artistic conventions raise surprisingly complex issues. But what do we make of these conventions when they leave the Napoleonic context of Revolution, the Second and Third Empires, and enter the democratic context of the U nited States, or for that matter, M exico, which boasts a wealth of Beaux-Arts-inspired monuments? Kirk Savage's excellent work on post $\mathrm{C}$ ivil War memorials begins to fill this gap. ${ }^{3} \mathrm{H}$ e shows how the post-bellum quandary of representing African-Americans materialized in the form of "N egro" body types that explicitly broke with classical tradition. Scholars of post-colonial memorials or of any non-western tradition

2. Sergiusz M ichalski, Public M onuments (London, Reaktion Books, 1998).

3. Kirk Savage, Standing Soldiers, Kneding Slaves: Race, War, and M onument in N ineteenthCentury America (Princeton U niversity Press, 1997). 
might learn how American sculptors confronted the bodies of former slaves in their art. M ichele Bogart's Public Sculpture and the Civic Ideal in N ew York City, I890- 1930 also makes good use of changing artistic conventions. ${ }^{4} \mathrm{Al}-$ though not as sweeping as M ichal ski's work, nor as politically charged as Savage's, Bogart's focus on America's "first city" treats both representative and atypical examples, and unlike M ichalski's work, it digs deeply into the public record, unearthing the debates behind memorialization. Bogart brings to life the people and institutions that waged battles over public space in order to claim some portion of it for their political agenda, embodied in the form of a memorial. The approach is important for architectural historians who wish to pursue the methods of social history, an approach I elaborated in an article on so called "living memorials", those "useful" memorials like parks, highways, and community centers that began to displace the purely devotional memorials of the pre-World War II era in the U nited States.5 M ore work needs to be done on the rise and fall of memorial conventions in various nations, especially in post-colonial nations, where monumentality and iconic sculpture continue to be dominant forms of memorialization.

Karal Ann M arling and John Wetenhall's work on the Iwo Jima M emorial has shown how public relations can hold memorial conventions above artistic conventions. ${ }^{6} \mathrm{O}$ ne of the most iconic of all American memorials, the I wo Jima memorial, a near classical pyramid of soldiers thrusting a flag into the captured ground of the Pacific island, is one of the rare successful figurative memorials to come out of World War II, when abstraction had muscled aside much of the figurative tradition in art. But this sculpture had a great deal of help. $\mathrm{N}$ ot only did it emerge out of a well-publicized photograph, but also a fullsized plaster cast was paraded through American cities as part of the drive to sell War Bonds. By the time the memorial was actually built, the image was al ready an icon. Albert Boime has approached memorials through the more general study of modern "icons" in the United States. The Unveiling of the $\mathrm{N}$ ational Icons, which includes some of the more popular memorials to grace

4. M ichele H elene Bogart, Public Sculpture and the Civic Ideal in N ew York City, I890-1930 (University of Chicago Press, 1989).

5. "Planning M emory: The R ise of Living M emorials in the United States during World War II", Art Bulletin (M arch 2002), 130-I47.

6. Karal Ann M arling and John Wetenhall, I wo Jima M onuments, M emories, and the American $\mathrm{H}$ ero (H arvard University Press, I99I). 
DOI: http://dx.doi.org/10.22201/iie.18703062e.2004.84.2166

I66

ANDREW M. SHANKEN

American consciousness, is important for treating a range of icons with Boime's characteristic sensitivity to images, and for including memorials in the synthetic context of political icons. ${ }^{7}$ T his is something that much of the work in the early i99os by historians failed to do.

The interest in memory has yielded a number of interesting and penetrating studies by leading scholars, many of whom shifted away from the subfields in which they established themselves. This is the case for Françoise Choay's The Invention of the H istoric M onument, an ambitious study of the origins of the very idea of public monuments from antiquity to the present. The book is essential reading. It theorizes the idea of the public monument, placing it in the historical context of the Enlightenment, nationalism, artistic practices, the "heritage industry", and preservation. What Boime did for the memorial as icon, Choay does for it as monument. H istorian D aniel J. Sherman wrote the best study of World War I memorials and Kurt Piehler, also an historian, surveyed World War II memorials, both paying close attention to politics. ${ }^{8}$

N ot surprisingly, war has been the focus of much of this work, and this has occasioned "big" history, taking on sweeping themes of politics, race, cataclysm and the cultural imagination, and the nature of history itself. Yet memorials come in different sizes. Increasingly memorials to local issues, events, and people have become common in public places, and they often arise from the work of otherwise anonymous people. The study of local memorials and of underrepresented groups who take part in the process of memorialization is subject of the recent reconsideration of southern memorials and the role of women and women's societies in creating them. ${ }^{9}$ Work of this kind can actually better represent the cultural meaning of commemorative practices. ${ }^{\text {Io }}$

7. The Unveiling of the National Icons: A Plea for Patriotic Iconodasm in a Nationalist Era (Cambridge U niversity Press, 1998).

8. D aniel J. Sherman, The Construction of M emory in Interwar France (U niversity of C hicago Press, 1999) and G. Kurt Piehler, Remembering War the American Way, 1783-1993 (Smithsonian Institution Press, 1995). World War I has been a particular interest of scholars in recent years. See Allen J. Frantzen, Bloody Good: Chivalry, Sacrifice and the G reat War (U niversity of Chicago Press, 2004).

9. Cynthia M ills and Pamela H. Simpson, editors, M onuments to the Lost Cause: Women, Art, and the Landscapes of Southern M emory (U niversity of Tennessee Press, 2003).

Io. Rebecca Solnit, "The Struggle of Dawning Intelligence: On M onuments and $\mathrm{N}$ ative Americans", H arvard D esign M agazine (Fall, 1999), 52-57. 
The point of departure for much of this work has been Pierre N ora's Lieux de M émoire, an ongoing catalogue of "sites of memory" in France, from memorials and major monuments, archives and museums to less expected sites like the Folies Bergère, and spaces where important political or cultural events took place: thus the ambiguous term "sites of memory", intended to capture the often intangible link between place and memory in public consciousness. $N$ ora's legacy for historiography, in part, is to see beyond the restrictions inherent in thinking of memorials in terms of discrete objects that arise from official attempts to consecrate or commemorate. Ironically, he creates some of the meaning surrounding these places by including them in his register, a list of memorable "sites." N ora is the muse for many excellent studies of memory, including J. M. W inter's Sites of M emory, Sites of M ourning, a study of representations of the first World War, although N ora collects only French sites of memory, while W inter attempts a comparative approach in an effort to put memorialization into cultural perspective. ${ }^{I I}$ The flexibility of N ora's inclusive approach is another of his drawbacks, since it uses the term memory without precision. In N ora's wake, many intellectual issues that are really about history are mislabeled as memory. Just replace the word memory with history in any history or art history text written in the last ten years and see if the correct word is not, in the end, history. To a seldom do scholars attend carefully to what $\mathrm{H}$ albwachs called "social memory", the ways in which groups of people craft, nurture, and share common recollections. Collective consciousness might also substitute for many of these misuses of the word memory, so much so that history now needs rescuing from memory.

Strictly speaking, memory is an incompletely understood physiological and psychological phenomenon, an operation in the brain that cannot be "shared" in any literal sense - the way computers allow flawless replication. While society sets aside places for memorials, the mind has not place as such for its memories. Time will tell whether insights from neuroscience will bear meaningfully on our understanding of cultural memory.12

In the cultural sense, memory is a social construct or contract, a constant negotiation between people, in part over what they decide not to forget and

II. Sites of M emory, Sites of M ourning: T he G reat War in European Cultural H istory (C ambridge University Press, 1995).

I2. H élène Lipstadt is currently trying to bridge findings in neuroscience with architectural history. 
how to shape it for posterity. W hen James Young writes of Germany's memory problem, for instance, he refers to the contests over history fought out through memorials in a nation with few sites that are not al ready choked with negative associations. ${ }^{13}$ It is no wonder that the counter-memorial tradition ( $G$ egen-D enkmal) arose in Germany, where the idea of an uncontroversial memorial is still unthinkable, as Young's accounts of counter-memorials show. In one example, Jochen Gerz and Esther Shaley-Gerz designed a disappearing column near $\mathrm{H}$ amburg (1986), eschewing what they consider the fascist imposition and permanence of the traditional monument. The artists coated a twelve-meter-high pillar with lead that allowed people to write on it with a metal stylus, thus actively engaging them in the process of memory. M onth by month, the column was lowered into the ground in stages, burying the writing and freeing more space, powerfully suggesting the inevitable (and perhaps essential) loss of memory and the willful neglect of the past, but also, the end of memory, or at least, the ineffable qualities of loss.

\section{Directions for Future Research}

O ne fruitful line of inquiry may be to see memorials as a form of vernacular, or, at least to see them as part of what Paul Groth and Todd W. Bressi call "O rdinary Landscapes." I4 M uch of the vernacular landscape tends to lie beneath high cultural radar, and even ordinary observation. The analogy to memorials is obvious. $M$ any memorials elude attention, an issue first raised in late $19^{\text {th }}$ century France according to $M$ ichal ski. They recede into oblivion, increasingly so as the object of the devotion slips out of the lived past. This is especially the case as the subjects and genres of memorials proliferate. ${ }^{\text {Is }}$ Yet the

I3. James Edward Young, The Texture of M emory: Holocaust M emorials and M eaning (Yale University Press, 1993).

I4. Paul G roth and Todd W. Bressi, editors, U nderstanding O rdinary L andscapes (Yale U niversity Press, 1997).

I5. Jay W inter makes this point implicit in his work on World War I memory. The scale of destruction of modern mechanized warfare, and especially warfare in an age of mass media, finds outlet in a number of cultural forms from film and performance to highways, on-line sites, and traditional memorials. The point also applies to local memorials to people or events that have been marginalized from canonical history. 
onus of neglect may rest elsewhere. The ossification of artistic conventions may lead to a language of memorialization that is so common that we fail to notice their presence. Another culprit may be the predictable spaces memorials tend to inhabit. We quarantine them en masse in swathes of neglected public space, strand them in traffic circles, or send them into isolation in public parks, where $i^{\text {th }}$ century strollers attuned to the picturesque and the cult of death once roamed. M any memorials become as common as curbs, fences, traffic lights, and commercial storefronts. In this way, memorials, which were meant to be exceptional, to stand outside of ordinary time and space, have too often become seamless parts of that space. 0 ne wonders if this neglect is not tantamount to a form of passive iconoclasm, or if it is the natural order of things: forgetting, as D avid Lowenthal and others assert, is an essential part of the process of mourning, and therefore, of memorialization.

Insights from cultural geography and sociology seem destined to enter this subfield, as well, particularly the work of $\mathrm{H}$ enri Lefebvre and Pierre Bourdieu, which challenges conventional understandings of place, shedding new light on the nature of memorial practices. Since memorials cannot be considered independently from their everyday - and special - uses, Lefebvre's insights about the social production of space inform commemorative practices, as well as the benign and assertive neglect of memorials. ${ }^{16} \mathrm{Far}$ from being inert, space, according to Lefebvre, is produced through social action. H is idea that "economic space" subordinates time to its own purposes opens up questions about memorialization as a concession of the state and as a form of veiled capitalism. Readers should think of the actual concessions that currently frame (spatially, economically, and politically) the Lincoln M emorial in Washington, D.C., as well as the capitalist implications of all commemorative activity. These considerations change radically outside of capitalism, but the application of Lefebvre may be no less appropriate. We might al so consider cases of memorial destruction in the former Soviet Union and more recently in Iraq after the American invasion in terms of the social destruction of space. $\mathrm{H}$ ere memorials marked time all too well.

Bourdieu's work on "fields of cultural production" suggests new ways of cracking open the complex public and private interests that do battle over the

16. H enri Lefebvre, La Production de I'Espace (Paris, Editions Anthropos, 1974). Translated to English in 1991. 
making of memorials, their placement, and their eventual use and neglect.17 All these forces can be understood in terms of Bourdieu's ideas of habitus, distinction, and "cultural capital," the last a term that has suffused academic writing since his initial usage. ${ }^{18} \mathrm{~T}$ he $\mathrm{M}$ arxist metaphor for the accumulated value amassed by a person or group is the currency through which groups spend their way to "owning" slivers of public space on which to stake their commemorative claims. The mall in Washington, D.C. is one of the most contested spaces for memorialization and the making of monuments. ${ }^{19}$ In recent years al one interest groups representing the $\mathrm{N}$ ational $\mathrm{M}$ useum of the American Indian, $\mathrm{N}$ ational M useum of African American $\mathrm{H}$ istory and $\mathrm{Cul}$ ture, and a $\mathrm{N}$ ational $\mathrm{M}$ emorial to World War II veterans have fought over the right to a plot on this hallowed ground, using the $M$ all itself as a symbol of enfranchisement. W ith a memorial, the idea becomes complex, since the political or social capital at stake applies to people now long dead, making the memorial more about the existing community and its demand to enact public commemoration.

I risk of making these issues too, $\mathrm{N}$ orth American in focus, but the efforts to memorialize the events of September II, 20or have made memorials more a matter of public debate than ever before. $\mathrm{N}$ ewspapers have run thousands of stories across the U nited States about the memorial at the site of the former World Trade C enter. In fact, there has been deep confusion about whether the buildings themselves can ever be free of some memorial function. This places on them a special burden, whether or not a separate memorial officially serves this role. While the ultimate form remains unsettled, both of the buildings and the memorial, one of the most stirring phenomena for study to emerge from the tragedy are the impromptu memorials that appeared overnight and grew by accretion daily as people came to view the site and place objects of remembrance there. ${ }^{20}$ In an age of intense interest in memorials, and shortly

17. See especially, Pierre Bourdieu, Fields of Cultural Production Essays on Art and Literature (Columbia U niversity Press, 1993).

I8. H élène Lipstadt has led the way in introducing Bourdieu into architectural history. See her "Learning from St. Louis: The Arch, the C anon, and Bourdieu," H arvard D esign M agazine (Summer, 200I), 4-I5.

I9. James S. Russell, "Crowding the Mall: The National M emorial Dilemma", Harvard D esign M agazine (Fall, 1999), 32-37.

20. Jeffrey L. D urbin, "Expressions of $M$ ass $G$ rief and $M$ ourning: The $M$ aterial Culture of $M$ akeshift $M$ emorials", M aterial Culture 35 (Fall, 2003), 22-47. Also, H arriet F. Senie, "M ourn- 
after the completion of a memorial to victims of the bombing of a Federal office building in $\mathrm{O}$ klahoma $\mathrm{C}$ ity, Americans witnessed a tragedy marked by instant and continuous memorialization. W hile these spontaneous acts of temporary memorialization easily found their place (and have found a permanent place in N ew York City collections), the formal process of placing a permanent memorial on the site has proven far more contentious. The claims of various "victims" - fire fighters, bankers, and policemen - have balkanized the process into a spirited and often dispiriting display of non-consensus. This is, however, the nettlesome democratic process at work, a process that gives a particular form (or formlessness) to memorials. Just compare the Vietnam $M$ emorial to its fascinating but disconcertingly unfocused Korean neighbor on the mall in Washington, D.C. O r, for that matter, count the multiplication of V ietnam memorials, which, depending on your vantage point, dissipate the power of M aya Lin's masterpiece or augment its power by "representing" the neglected agendas of women and other groups.

In the end, the controversies surrounding individual memorials may be seen as part of the process of grieving, if not of memorialization, itself. The idea reminds us that architecture is not just the fait accompli, the finished product in its supposed final glory, but the many steps along the way from its conception and design to the photographs taken after it is built. M emorials, perhaps more than ordinary buildings, demand study of all of these steps. $N$ eedless to say, all of these issues take on a radically different cast when applied to memorials in nations like Iraq and I ran, South Africa, Cambodia, or any nation in which authoritarian power guards official memory, and does so in the conspicuous presence of tragedy or abuse. $\$$

ing in Protest: Spontaneous M emorials and the Sacralization of Public Space", H arvard D esign M agazine (Fall, 1999), 23-27. 
DOI: http://dx.doi.org/10.22201/iie.18703062e.2004.84.2166

172

ANDREW M. SHANKEN

Other key sources in the history of memorials

Borg, Alan, War M emorialsfrom Antiquity to the Present, London, Leo Cooper, I99I. $\mathrm{H}$ obsbawm, Eric and Terence Ranger, editors, The Invention of Tradition, Cambridge,

Cambridge U niversity Press, 1983.

M clntyre, Colin, M onuments of War: H ow to Read a War M emorial, London, Robert $\mathrm{H}$ ale, 1990 .

M ayo, James M ., War M emorials as Political Landscape: The American Experience and Beyond, N ew York, Praeger, 1988.

M osse, G eorge L., Fallen Soldiers. Reshaping the M emory of theWorld Wars, N ew York, Oxford U niversity Press, 1990. के 